\title{
Letter from the Editor-in-Chief: Exit, stage left
}

\section{Lorraine Eden}

Journal of International Business Studies (2010) 41, |439-1443.

doi: | 0. I057/jibs.20 0.43
This is the last issue of the Journal of International Business Studies (JIBS) published under my watch as Editor-in-Chief (EIC). The issue contains six articles and two research notes; several of the papers offer new insights on research methods and metrics in international business (IB) studies. Beugelsdijk, Hennart, Slangen and Smeets demonstrate and explain why FDI stocks are a biased measure of MNE affiliate activity. A new metric to measuring crossborder distance is proposed by Berry, Guillen and Zhou. Jensen, Li and Rahman critique the proxies developed from cross-national firm-level surveys of corruption. How political connections can create problems for the accuracy of analysts' forecasts in countries varying in their levels of public corruption is examined by Chen, Ding and Kim. Blomkvist, Kappen and Zander explore the innovation-creating role played by foreign subsidiaries within the multinational's network. $\mathrm{Li}$ and $\mathrm{Li}$ use real options theory to explore the tradeoffs between flexibility and commitment in mode-of-entry strategies. The issue concludes with two research notes. Gao and Pan examine the dynamic process of sequential entries. Ellis wraps up the issue by returning to the general theme of research methods and metrics in IB reseach with an analysis of the importance of effect sizes and a call for authors to evaluate the substantive as well as the statistical significance of their IB research.

\section{FAREWELL EDITORIALS - PERIODIC SNAPSHOTS OF וBS}

In preparing my last JIBS editorial, I went back and read the first and last editorials written by my predecessors to see how they assessed their experiences. There have been six EICs before me: Ernest W. Ogram Jr. (1970-1975), William A. Dymsza (1975-1984), David A. Ricks (1985-1992), Paul W. Beamish (1993-1997), Thomas L. Brewer (1997-2002) and Arie Y. Lewin (2002-2007). The pattern they trace in their exit letters is a "good news" story of birth, development and growing maturity for the journal.

Ernest Ogram, the first JIBS editor, documents the founding years at Georgia State University (Ogram, 1981). His university provided $\$ 2000$ to defray a 300-print run twice a year plus the half-time assistance of a doctoral student. In addition, the Association of Business Education in International Business, which later became the Academy of International Business (AIB), provided JIBS with $50 \%$ of member dues. With the Association having about 200 members and dues at $\$ 10$, the total JIBS budget must have been under $\$ 3000 .{ }^{1}$ Ogram notes that the two biggest problems faced by the journal were quality of manuscripts and slow turnaround time (issues that still bedevil editors today). Reminders to reviewers 
Wall into the new millennium. David Ricks captained JIBS for eight years, starting in 1985; his last editorial, less than a page long, focuses on the benefits and the costs of being EIC. On the benefit side, a memorable quote is, "I have learned a great deal - so much, in fact, that I now wonder what I knew before being selected to serve"; on the cost side, he notes that, "the job has probably taken the full-time equivalent of three years of my life" (Ricks, 1992: v). Paul Beamish edited JIBS for five years; his last editorial identifies JIBS a "multifunctional, cross-disciplinary" journal and thanks the various stakeholders who supported JIBS during his term (Beamish, 1997). Thomas Brewer's last editorial highlights the symposia published during his five-year term, the JIBS website hosted by Copenhagen Business School, and also thanks various stakeholders (Brewer, 2002).

My predecessor Arie Lewin concluded his six-year term with an editorial explaining how he and his team of 38 departmental and 22 special departmental editors had attempted to change JIBS. His goal was for JIBS "to become a recognized top tier journal, acclaimed for redirecting International Business research and for defining new directions" (Lewin, 2007: 1953). By vastly expanding the number of editors, decentralizing decision making, and introducing annual Conferences on Emerging Research Frontiers, Lewin attempted to make JIBS more pluralist, exciting and impactful. In the editorial, Lewin rails against "creeping parochialism" and argues that JIBS should be redirecting and redefining the field of IB studies through greater variation and more editorial risk-taking.

Looking across these earlier editorial farewells, one can trace the trajectory of JIBS from its earliest beginnings. While these editorials were not meant to be scholarly assessments of changes in the content, scope or quality of JIBS, they are useful snapshots - historical markers - of the activities of the six previous JIBS Editors-in-Chief. And now it is my turn.

\section{GOAL \# 1: AN UNAMBIGUOUS "A" SCHOLARLY BUSINESS JOURNAL}

My application for the position of JIBS EIC, submitted to the AIB Executive Board in October 2006, stated that my editorial team would have "one main goal: to increase the quality of the journal such that it is seen as an unambiguous 'A-level' journal in business schools around the world". In all of our activities, my editorial team has been guided by that goal, which is clear in our 
mission statement: To publish insightful and impactful articles on international business that are widely read and cited by business and management scholars. Our intention was not to reinvent the wheel, but rather to build on what we saw as the best and most successful activities of previous JIBS editors.

We started by revising the JIBS Statement of Editorial Policy, clarifying the field of IB studies as having six subfields, briefly summarized as: (1) MNE activities, strategies, structures and decisionmaking processes; (2) MNE interactions with other actors, organizations and institutions; (3) crossborder activities of businesses; (4) impacts of the international environment on the activities, strategies, structures and decision-making processes of businesses; (5) cross-country comparative studies of businesses, business processes and organizational behavior, and (6) international dimensions of organizational forms and activities. In the statement, we emphasized the interdisciplinary nature of IB research, seeing JIBS as a "row" journal that brings together scholars from disciplines ("columns"), with a common interest in IB research.

We developed three clear criteria for assessing manuscripts: fit, quality and contribution to IB studies. As editors, we worked hard with authors to build better IB theories, test these theories with up-todate qualitative and quantitative empirical methods, and fine-tune their papers so they became more insightful and impactful. We expanded on these themes in regular Letters from the Editor-inChief and Letters from the Editors, which are now freely available for download from the JIBS website. We gave dozens of presentations and training workshops, which are also posted and available for download from the JIBS Activities page hosted by the Texas A\&M CIBER. We used Special Issues as a method to encourage IB scholarship in important but understudied areas such as qualitative research and multi-level research in IB. Other important activities were the celebrations for the JIBS 40th and AIB 50th Anniversaries (including the "Back to 1970" JIBS Decade Awards and the "Innovations in IB Theory" Anniversary Issue), the JIBS Paper Development Workshops at the AIB meetings, and upgrading and expanding the JIBS website (especially, Advance Online Publication of accepted articles). These activities are summarized and evaluated elsewhere (Eden, 2010a,b) so I simply mention them here.

Whether the overall impact of these innovations and activities will be the achievement of the goal stated in my JIBS EIC application - that JIBS becomes an unambiguous " $\mathrm{A}$ " top-tier journal - is perhaps too soon to tell. Thomson's Web of Science metrics are one measure, but those numbers are in the future (Eden, 2009; 2010b,c). The real proof will come when scholars read our JIBS articles and declare, "That's interesting! What would happen if ....", and then use insights from these articles to build their own research stream.

\section{GOAL \#2: AN EFFICIENT AND EFFECTIVE EDITORIAL PROCESS}

My more prosaic - and often repeated - goal when I became JIBS EIC was to "make the trains run on time"; that is, to develop, codify and implement lean-production techniques that would make the journal editorial process both more efficient (getting things done right) and more effective (getting the right things done). Our first tasks were challenging ones, all transition related. We moved from the outmoded, outdated Outdare web platform to a newly designed-for-JIBS Manuscript Central web platform; moved the JIBS Office from Duke University to Michigan State University; and moved 63 in-transition manuscripts from the outgoing to the incoming editorial team.

Perhaps the most important of the new policies and procedures we put in place over the past three years have been (1) our focus on ethics in the publication process (see Eden, 2010d) and development of (what we believe to be) the first Code of Ethics for a scholarly business journal; (2) new procedures for selecting and managing Special Issues; (3) formal Manuals for all JIBS Editors and for the EIC documenting JIBS policies and procedures; (4) formal selection processes for membership in the JIBS Consulting Editor and Editorial Review Boards; and (5) metrics for rating reviews and selecting best reviewer awards. All of these policies were developed through close collaboration among the editorial team and consultation with the relevant stakeholders.

One of my commitments in my EIC Application was to regularly provide metrics on the journal publication process. (I felt so strongly about this that we wrote it into the Editor section of the JIBS Code of Ethics.) Let me now provide my final set of statistics on "making the trains run on time", updating Eden (2009), my semi-annual reports to the AIB Executive Board and my annual reports to the AIB General Meeting.

Between July 2007 when my editors and I first began processing manuscripts and June 2010 when the incoming team began to handle all new submissions, we received 1736 new submissions 
(1259 articles, 42 research notes and 20 perspectives, 6 commentaries, and 409 Special Issue submissions); we therefore averaged 48 manuscripts per month. In 2008, we published eight issues of JIBS totaling 1391 pages; in 2009, nine issues with 1605 pages; and again this year JIBS will publish nine issues with 1680 pages.

The overall desk rejection for the 1736 submissions during these 36 months was $48 \%$; $36 \%$ of submissions were rejected by the Reviewing Editor and/or EIC and $12 \%$ by Area Editors. All desk rejections received a letter explaining why the manuscript was not being sent for external review; normally, detailed comments were provided to the authors about how to improve the paper and where else to submit the manuscript. The average number of days for desk rejection at the Reviewing Editor stage was 4.5 days. The primary reason for desk rejection at the RE/EIC stage was lack of fit with the JIBS Statement of Editorial Policy. ${ }^{2}$ Perhaps 10-15\% of the desk-rejected manuscripts simultaneously received an invitation to revise and resubmit to JIBS; these were cases where the manuscript was promising and had identifiable problems that could be fixed (e.g., failure to test and correct for common method bias, no attempt to frame the paper for an IB audience). The high desk rejection rate has been a long-standing concern to me and my editors; elsewhere I have written about the various ways we have tried to reduce the desk rejection rate (Eden, 2010b); I refer interested readers to my earlier editorial.

We sent out 910 original manuscripts for firstround review. Almost $80 \%$ of these manuscripts received three or more external review reports. Average turnaround time from first submission to first editorial decision for these manuscripts was 70 days. Revise-and-resubmit invitations were given to $26 \%$ of the manuscripts that were sent out for review; the other $74 \%$ were rejected from further review. In addition to the detailed reviews, authors were provided with developmental decision letters to help the authors in revising their manuscripts for submission elsewhere.

At the R1 stage, $30 \%$ of the resubmissions were rejected after external review, $17 \%$ were conditionally accepted and 4\% accepted for publication, and the remainder invited to revise and resubmit. At the R2 stage, $7 \%$ were rejected, 32\% conditionally accepted and $35 \%$ accepted for publication, and the remainder invited to revise and resubmit. At the R3 stage, $75 \%$ of resubmissions were accepted and $20 \%$ conditionally accepted; at the R4/5 stage all were accepted or conditionally accepted for publication.
The average number of days to decision at each stage were R1 (63), R2 (45), R3 (28) and R4/5 (14). These results are quite consistent with those reported in Eden (2009).

\section{EXIT, STAGE LEFT}

A farewell editorial would not be complete without thanking individuals who worked with me over this period, especially the core group who ran the journal: Managing Editor Anne Hoekman, Editorial Assistant Deanna Johnston, and my Editors (Daniel Bello, Sea-Jin Chang, Witold Henisz, Lee Radebaugh, Lemma Senbet, Anand Swaminathan, Rosalie Tung, Alain Verbeke and Srilata Zaheer). We have been an incredibly tight and supportive team, the most effective "virtual" team with whom I have ever worked. I also thank the members of the JIBS Consulting Editors Board and Editorial Review Board and Guest Editors of our Special Issues for their dedicated service to the journal.

Tunga Kiyak, AIB Managing Director, played several critically important, behind-the-scenes roles for JIBS, ranging from helping set up Manuscript Central and the JIBS email accounts to facilitating JIBS activities at the AIB meetings such as the excellent Paper Development Workshops organized by Laszlo Tihanyi. I have also worked very closely with David Bull, our Palgrave editor, and thank him and his staff for their dedication and commitment to JIBS. They have played a vital role in raising the visibility and stature of the journal. Many other individuals too numerous to name here also played important roles for JIBS (e.g. my "kitchen cabinet" of journal editors, my husband and family). A few individuals received special recognitions at the AIB meetings in Rio de Janeiro. To all, I extend my heartfelt thanks for your help and support.

I want to also thank the Department of Management, the Center for International Business Studies (our CIBER) and the Dean's Office in the Mays Business School at Texas A\&M University for their unwavering support of JIBS and their commitment to IB studies. In particular, I want to thank my department head, Murray Barrick. My department housed four Editors-in-Chief and two Associate Editors of six scholarly business journals during my JIBS tenure. The willingness of my department and college to allocate time, personnel and funds to six journals is strong evidence of the commitment to scholarship and the spirit of volunteerism for which Texas A\&M is so well known.

After the AIB Executive in late December 2009 announced its selection of John Cantwell as the 
next EIC, my editors and I agreed that we would work hard to create a smooth transition between the two teams. Anne Hoekman, who is staying on as JIBS Managing Editor, has played a pivotal role in the transition. Our goal is an orderly and uneventful departure in December 2010. I wish John Cantwell and his editorial team great success as the next stewards of JIBS.

Let me end by saying that JIBS has been an intense, all-consuming activity for my editorial team; we have been passionate about the journal and committed to improving its quality, visibility and impact. I am proud of what I and my editors have accomplished. We leave JIBS a stronger journal, one that is more interdisciplinary, insightful and impactful.

Like Snagglepuss in the Hanna-Barbera cartoon, now "Exit, stage left."

\section{ACKNOWLEDGEMENTS}

I thank Anne Hoekman who prepared the 2007-2010 JIBS publication process statistics reported here, and Paul Beamish, David Bull, Alan Rugman, Alain Verbeke and Mary Ann von Glinow for helpful comments on earlier drafts of this editorial.

\section{REFERENCES}

Beamish, P. 1997. Letter from the Editor-in-Chief. Journal of International Business Studies, 28(4): iv-v.

Brewer, T. 2002. Letter from the Editor-in-Chief. Journal of International Business Studies, 33(4): xi-xii.

Dymsza, W. A. 1984. Ten years of JIBS at Rutgers School of Management. Journal of International Business Studies, 15(3): 9-12.

Eden, L. 2009. Letter from the Editor-in-Chief: JIBS status report - the first 18 months. Journal of International Business Studies, 40(5): 713-718.

Eden, L. 2010a. Adding spice to our scholarly journals: The JIBS experience. International Studies Quarterly, 54(3): 903-909.

Eden, L. 2010b. Letter from the Editor-in-Chief: JIBS publication criteria and their consequences. Journal of International Business Studies, 41(7): 1093-1098.

\section{NOTES}

${ }^{1}$ Compare this with the 2010 JIBS print distribution of approximately 4300 copies of 9 issues per year. Even this large number significantly underestimates the visibility of JIBS since it obscures the importance of networked institutional access and JIBS website downloads. AIB members receive the journal free as part of their membership dues. JIBS profits now finance a major portion of the AIB budget. From small acorns do big oak trees grow!

${ }^{2}$ Perhaps $80 \%$ of my desk rejections were on "fit" grounds (i.e., single country studies on domestic topics, papers that were at best tangentially related to IB, education-related papers, pure economics or finance papers, papers using undergraduate student samples to test managers' decisions, government documents, consulting projects, prescriptive policy papers, and monographs). The rest were rejected on "quality" grounds (i.e., no or little theory development, papers retesting an existing theory on a new dataset, number counting/ranking studies with no theory, papers with empirical methods problems, and papers submitted far too early). Often, manuscripts were desk rejected on both criteria.

Eden, L. 2010c. Letter from the Editor-in-Chief: Standing on the shoulders. Journal of International Business Studies, 41(5): 755-758.

Eden, L. 2010d. Letter from the Editor-in-Chief: Scientists behaving badly. Journal of International Business Studies, 41(4): 561-566.

Lewin, A. Y. 2007. Letter from the Editor. Journal of International Business Studies, 38(7): 1053-1054.

Ogram Jr, E. W. 1981. The early days of JIBS at Georgia State University, 1970-1975. Journal of International Business Studies, 12(1): 7-9.

Ricks, D. A. 1992. Letter from the Editor-in-Chief. Journal of International Business Studies, 23(4): v. 